\title{
STRATEGI THINK, TALK, WRITE UNTUK MENINGKATKAN KETERAMPILAN MENULIS LA DISPONIBILITÉ DAN LA VOLONTÉ
}

\author{
Sri Moerni \\ SMA Negeri 10 Yogyakarta \\ moernisri3@gmail.com
}

\begin{abstract}
Abstrak: Tujuan penelitian adalah meningkatkan keterampilan menulis dalam bahasa Perancis pada kompetensi dasar la disponibilité dan la volonté dengan menggunakan strategi Think, Talk, Write bagi siswa kelas XI IPS 1 SMA Negeri 10 Yogyakarta tahun pelajaran 2019-2020. Metode penelitian yang digunakan adalahPenelitian Tindakan Kelas. Didalam penelitian ini diaparkan awal pemberian perlakuan sampai dampak dari perlakuan tersebut. Hasil penelitian menunjukkan adanya 1). Kenaikan hasil belajar dari prasiklus ke siklus satu sebesar 19,03\% dan dari siklus satu ke siklus kedua sebesar 14,29\%. 2) Dengan strategi pembelajaran Think, Talk, Write ini, diawali dengan siswa memahami materi secara individu melalui kegiatan membaca, berdiskusi dalam kelompok, setiap kelompok terdiri atas 3 orang, dan kegiatan pembelajaran diakhiri dengan siswa menuliskan gagasan secara mandiri. Siswa menjadi lebih fokus dan antusias dalam mengikuti pembelajaran. Dengan strategi Think, Talk, Write maka empat tahapan kompetensi belajar bahasa dilalui dengan baik, mulai dari memahami, berbicara, membaca dan menulis.
\end{abstract}

Kata kunci: strategi think, talk, write, keterampilan menulis, kompetensi la disponibilité dan la volonté

\section{THINK, TALK, WRITE STRATEGY TO IMPROVE WRITING SKILLS LA DISPONIBILITÉ AND LA VOLONTÉ}

\begin{abstract}
The purpose of this research is to improve writing skills in French on the basic competencies of la disponibilité and la volonté by using Think, Talk, Write strategies for students of class XI IPS 1 in SMA Negeri 10 Yogyakarta in the academic year 2019-2020. The research method used was Classroom Action Research. In this study the initial treatment was given to the impact of the treatment. The results showed 1). The increase in learning outcomes from pre cycle to cycle one was $19.03 \%$ and from cycle one to cycle two was $14.29 \%$. 2) With this Think, Talk, write learning strategy, it begins with students understanding the material individually through reading activities, discussing in groups, each group consists of 3 people, and the learning activities end with students writing their ideas independently. Students become more focused and enthusiastic in participating in learning. With the Think, Talk, write strategy, the four stages of language learning competency are passed well, starting from understanding, speaking, reading and writing.

Keywords: think, talk, write strategy, writing skills, la disponibilité and la volonté competencies
\end{abstract}

\section{PENDAHULUAN}

Tujuan Pendidikan Nasional menurut Undang-Undang No. 20, Tahun 2003 menyebutkan, "Pendidikan nasional berfungsi mengembangkan kemampuan dan membentuk watak serta peradaban bangsa yang bermartabat dalam rangka mencerdaskan kehidupan bangsa, bertujuan untuk berkembangnya potensi peserta didik agar menjadi manusia yang beriman dan bertakwa kepada Tuhan Yang Maha Esa, berakhlak mulia, sehat, berilmu, cakap, kreatif, mandiri, dan menjadi warga negara yang demokratis serta bertanggung jawab."

Bahasa Perancis sebagai salah satu mata pelajaran lintas minat di SMA Negeri 10
Yogyakarta, dimaksudkan untuk memberi warna pada satuan pendidikan, sehingga kelak dapat bermanfaat untuk pengembangan diri peserta didik.

Bahasa Prancis seperti halnya bahasa yang lain, mempunyai 4 keterampilan berbahasa yang harus dikuasai peserta didik, yakni keterampilan memahami atau compréhension orale, keterampilan berbicara atau production orale, keterampilan membaca atau compréhension écrite dan menulis atau production écrite. Keterampilan menulis meskipun terletak pada bagian akhir dari empat keterampilan berbahasa, namun kompetensi menulis merupakan keterampilan vital yang harus dikuasai pembelajar bahasa. 
Namun pada kenyataannya, keterampilan menulis siswa khususnya kelas XI IPS1 SMA Negeri 10 Yogyakarta dalam pembelajaran bahasa Perancis masih rendah, dibuktikan dengan $50 \%$ nilai ulangan harian siswa dibawah KKM dan dalam mengikuti pembelajaran siswa kurang bersemangat. Siswa masih kurang menguasai tata bahasa dan kosa kata sebagai prasyarat supaya dapat menulis dengan baik, sehingga siswa belum dapat mengungkapkan gagasan secara tertulis dengan baik.

Berkaitan dengan kondisi ideal dan kondisi nyata yang saling bertentangan seperti diuraikan di atas, maka diperlukan model pembelajaran yang relevan sehingga dapat mendorong siswa untuk dapat menulis dengan baik. Dengan menggunakan strategi belajar Think, Talk, Write ini diharapkan dapat memberikan suasana baru dalam pembelajaran.

Huda (2015:5) mengatakan bahwa pembelajaran sebagai suatu perubahan perilaku dan kapasitas.

Dari pendapat di atas dapat disimpulkan bahwa pembelajaran bahasa merupakan suatu pembelajaran keterampilan berbahasa dan kaidah kebahasaan yang secara sadar ditindaklanjuti dengan usaha mengubah perilaku berbahasa seperti penutur bahasa yang dipelajari.

Secara umum, pembelajar bahasa mempelajari sebuah bahasa karena ingin menguasai bahasa tersebut dan dapat menggunakannya untuk berkomunikasi dengan orang lain. Secara rinci, tujuan penguasaan bahasa antara lain sebagai berikut: memiliki tujuan praktis supaya dapat berkomunikasi dengan pemilik bahasa, memiliki kemahiran dalam penguasaan keindahan berbahasa, dapat mengungkapkan nilai kebudayaan yang terkandung dalam bahasa tersebut, dan mempelajari bahasa sebagai objeknya (Pringgawidagda, 2002: 13).

Dari syarat- syarat pembelajaran bahasa di atas dapat disimpulkan bahwa dengan mempelajari bahasa secara benar maka seseorang akan dapat berkomunikasi dengan baik dengan pemilik bahasa tersebut, dapat menguasai keindahan bahasanya, memahami kebudayaannya dan menguasai bahasa tersebut secara ilmu kebahasaan.

Pembelajaran bahasa Perancis sebagai bahasa asing atau français langue étrangère merupakan mata pelajaran yang mengembangkan keterampilan lisan dan keterampilan tulis. Pembelajaran bahasa Perancis bertujuan agar para peserta didik memiliki kemampuan dasar dalam keterampilan mendengarkan, berbicara, membaca dan menulis untuk berkomunikasi secara sederhana.

Bermula dari keterampilan mendengarkan dan diakhiri dengan keterampilan menulis dengan materi yang diajarkan berupa wacana lisan dan tulisan berbentuk paparan atau dialog sederhana tentang salutation, se presenter, presenter quelqu'un, l'heure, des lieux publics, les caractères, l'instruction, les chansons, proposer des opinions, la disponibilité et la volonté, l'interdiction, féliciter, se situer de l'espace, la routine, le passé composé, féliciter, l'obligation, l'objectif, demander quelqu'un de faire quelque chose, le texte procedure, le future, le texte naratif, le fable française ( Permendikbud nomor 37 tahun 2018:496).

Tagliante (1994:6) menyatakan bahwa "C'est tout simplement le français langue d'apprentissage pour tous ceux qui ont une autre langue que le français comme langue maternelle. Le FLE peut être aussi la langue dans lequelle un étudiant non francophone suivra ses études (c'est le cas par exemple, de l'enseignement scientifique supérieur au Maroc)". Maksud dari pengertian tersebut di atas yaitu bahasa Prancis dipelajari untuk semua orang, yang telah mempunyai bahasa lain sebagai bahasa ibu. Bahasa Prancis sebagai bahasa asing dapat dipelajari tidak hanya oleh orang-orang dari negara penutur bahasa Prancis (francophonie) tetapi juga dapat dari daerah lain. (contoh: seorang ilmuwan yang mengikuti pendidikan di Maroko).

Keterampilan menulis diletakkan pada bagian akhir karena keterampilan menulis selalu dianggap sebagai keterampilan yang paling sulit. Nurgiyantoro (2013: 422) menyatakan bahwa aktivitas menulis merupakan bentuk kompetensi berbahasa paling akhir dikuasai pembelajar bahasa setelah kompetensi mendengar, berbicara, dan membaca. Selain itu keterampilan menulis dianggap lebih sulit dibanding ketiga keterampilan sebelumnya.

Menulis bahasa Perancis di SMA cenderung lebih difokuskan pada tujuan pernyataan diri. Siswa akan diminta untuk belajar menulis tentang identitas diri sendiri, identitas keluarga, jadwal di sekolah, denah rumah, dan lain-lain. Selanjutnya, dijelaskan dalam Permendikbud nomor 37 tahun 2018 
bahwa kompetensi dasar pengetahuan dan keterampilan berbahasa Perancis yang harus dikuasai siswa kelas XI adalah proposer des opinions, la disponibilité et la volonté, l'interdiction, fèliciter, se situer de l'espace, la routine, le passé composé, les messages courts, le texte descriptif, et la poème.

Berdasarkan penilaian

DELF

keterampilan menulis bahasa Prancis di SMA tergolong pada niveau A1. Dalam Niveau A1 siswa SMA sudah dapat dikatakan mampu menyusun frasa, kalimat sederhana tentang kehidupan sehari-hari.Berikut ini adalah format penilaian DELF niveau A1 oleh Breton (2005: 86) yang telah disesuaikan yang meliputi respect de la consigne atau dapat mematuhi perintah yang terdapat dalam soal, correction sociolinguistique peut choisir un register de langue adapté au destinataire (tu/vous) penilaian secara sosiolinguistik, capacité à informer ou à décrire kemampuan menulis dan memberi informasi, lexique tentang ejaan, morphosyntaxe ejaan secara gramatikal, cohérence ou cohésion artinya mampu menghubungkan antar kalimat dengan menggunakan kata hubung yang tepat.

Strategi Think, Talk, Write ini memfasilitasi latihan berbahasa baik secara lisan dan tertulis. Strategi pembelajaran Think, Talk, Write yang diperkenalkan oleh Huinker dan Lughin (Huda, 2015: 218) dengan alasan bahwa strategi Think, Talk, Write ini membangun secara tepat untuk berpikir dan merefleksikan, dan untuk mengorganisasikan ide-ide serta mengetes ide tersebut sebelum siswa diminta untuk menulis.

Strategi dilakukan secara runtut berdasarkan urutan namanya, yaitu berpikir (think), berbicara (talk), menulis (write). Alur kemajuan strategi Think, Talk, Write dimulai dari keterlibatan siswa dalam berpikir (think) atau berdialog dengan dirinya sendiri setelah proses membaca, selanjutnya berbicara dan membagi ide (talk) dengan temannya sebelum menulis. Suasana seperti ini lebih efektif jika dilakukan dalam kelompok heterogen dengan 3-5 siswa. Dalam kelompok ini siswa diminta membaca, membuat catatan kecil, menjelaskan, mendengarkan dan membagi ide bersama teman kemudian mengungkapkannya melalui tulisan (Yamin dan Ansari, 2009: 84).

Langkah-langkah penggunaan strategi Think, Talk, Write menurut Huda (2015:218) adalah sebagai berikut: siswa membaca teks, membuat catatan kecil mengenai hal yang dibacanya, lalu secara individu siswa memikirkan tentang isi atau makna teks tersebut, selanjutnya siswa masuk dalam kelompok dan mengadakan kegiatan diskusi tentang hal-hal yang telah dibaca sebelumnya, dalam kegiatan diskusi siswa secara aktif mengutarakan pendapat-pendapatnya. Langkah selanjutnya, siswa mengkonstruksi kembali pengetahuan mereka dalam bentuk tulisan, kegiatan akhir pembelajaran yaitu refleksi dan kesimpulan dari materi yang dipelajari.

Penelitian yang relevan dengan Skripsi Rikha Vivit Ramadhani tahun 2015 berjudul Keefektifan Strategi Think, Talk, Write dalam Pembelajaran Membaca Pemahaman Teks Eksplanasi pada Siswa Kelas VII SMP N 1 Prambanan.Tujuan penelitian ini yaitu: pertama, mengetahui perbedaan kemampuan membaca pemahaman teks eksplanasi yang signifikan antara siswa yang mendapat pembelajaran menggunakan strategi Think, Talk, Write. Berdasarkan hasil analisis data dalam penelitian ini, maka dapat disimpulkan bahwa strategi Think, Talk, Write efektif digunakan dalam pembelajaran membaca pemahaman teks eksplanasi pada siswa kelas VII SMP Negeri I Prambanan.

Skripsi Lista Meilani tahun 2015 berjudul Keefektifan Strategi Think, Talk, Write (TTW) dalam Pembelajaran Menulis Teks Negosiasi pada Siswa Kelas X SMA Negeri 2 Wates Kabupaten kulon Progo DIY. Tujuan penelitian untuk mengetahui keefektifan penggunaan strategi Think-Talk-Write dalam pembelajaran menulis teks negosiasi siswa kelas X SMA Negeri 2 Wates. Hasil penelitian menunjukkan bahwa penggunaan strategi Think-Talk-Write sangat efektif diterapkan kepada siswa untuk meningkatkan keterampilan menulis teks negosiasi.

Berdasarkan kerangka berpikir di atas dapat dikemukakan hipotesis, bahwa: penerapan strategi pembelajaran Think, Talk, Write dapat meningkatkan keterampilan menulis Bahasa Perancis pada kompetensi la disponibilité dan la volonté bagi siswa kelas XI IPS 1 SMA Negeri 10 Yogyakarta.

\section{METODE PENELITIAN Jenis Penelitian}

Penelitian ini tergolong dalam jenis penelitian tindakan kelas atau Classroom Action Research (CAR). Di dalam penelitian ini akan dipaparkan sebab akibat yang ditimbulkan dari perlakuan, memaparkan apa 
saja yang terjadi ketika perlakuan diberikan, dan memaparkan seluruh proses sejak awal pemberian perlakuan sampai dengan dampak perlakuan tersebut. Arikunta 2015:2 menyebutkan bahwa Penelitian Tindakan Kelas adalah memaparkan baik proses maupun hasil, dilakukan di kelasnya untuk meningkatkan kualitas pembelajaran.

Penelitian tindakan kelas ini dilaksanakan dalam dua siklus. Setiap siklus diawali dengan menyusun perencanaan, pelaksanaan kegiatan, observasi dan refleksi hasil kegiatan.

Berdasarkan hasil observasi dan refleksi yang dilakukan oleh peneliti, observer dan siswa, maka dirangcang pelaksanaan siklus kedua yang dimulai dengan menyusun perencanaan, melaksanakan tindakan, melakukan observasi dan refleksi.

\section{Waktu dan Tempat Penelitian}

Kegiatan penelitian tindakan kelas ini dilaksanakan di SMA Negeri 10 Yogyakarta yang terletak di jalan Gadean nomor 5 Ngupasan Yogyakarta dan dilaksanakan selama 4 bulan yaitu tanggal 1 Agustus sampai 26 November 2019 pada semester 1 tahun pelajaran 2019-2020.

\section{Subjek Penelitian}

Subjek penelitian adalah kelas XI IPS1 SMA Negeri 10 Yogyakarta tahun pelajaran 2019-2020 berjumlah 21 siswa terdiri 7 lakilaki dan 14 perempuan. Mata pelajaran yang diteliti adalah Bahasa Perancis pada materi la disponibilité dan la volonté

\section{Prosedur Penelitian \\ Siklus 1}

a. Rencana tindakan

1) Menyusun RPP

Kegiatan penelitian diawali dengan menyusun Rencana Pelaksanaan Pembelajaran untuk kelas XI IPS1 SMA Negeri 10 Yogyakarta dengan Kompetensi Dasar 3.2 yaitu mengekspresikan tindak tutur untuk menyatakan dan menanyakan kemampuan dan kemauan (la disponibilité et la volonté) melakukan suatu tindakan dengan memperhatikan fungsi sosial, struktur teks, dan unsur kebahasaan pada teks interpersonal dan teks transaksional tulis dan lisan, dan kompetensi dasar 4.2 menerapkan tindak tutur untuk menyatakan dan menanyakan kemampuan dan kemauan (la disponibilité et la volonté) melakukan suatu tindakan dengan memperhatikan fungsi sosial, struktur teks, dan unsur kebahasaan pada teks interpersonal dan teks transaksional tulis dan lisan. Adapun langkah-langkah pembelajaran yang akan dilaksanakan terjabarkan di bawah ini:

a) Siswa membaca teks yang berisi gambar dan kata kerja yang berkaitan dengan la tàche domestique

b) Siswa mencatat informasi-informasi penting yang berkaitan dengan aktivitas domestique sesuai dengan pertanyaan yang diajukan guru.

c) Siswa berkelompok (setiap kelompok terdiri atas 4 siswa) dan secara aktif mendiskusikan aktivitas-aktivitas yang terdapat di dalam teks dan mendiskusikan konjugasi kata kerja-kata kerja di dalam teks.

d) Siswa menemukan kesimpulan di dalam diskusi ini dan mempresentasikan hasil diskusinya di depan kelas.

e) Siswa kembali ke tempat duduk masingmasing dan secara mandiri menuliskan kegiatan yang berkaitan dengan tugas tugas domestique mereka.

f) Siswa mempresentasikan hasil tulisan mereka di depan kelas.

2) Menyusun lembar kerja

Lembar kerja yang harus disiapkan adalah lembar kerja berupa soal-soal pretes, teks yang harus dibaca siswa pada bagian awal pertemuan, lembar diskusi siswa dan soal postes.

3) Menyusun instrumen penelitian

Instrumen penelitian yang disiapkan adalah lembar observasi kegiatan guru sebelum melaksanakan tindakan, lembar observasi guru selama melaksanakan tindakan dan lembar observasi evaluasi pelaksanaan tindakan. Lembar observasi untuk siswa meliputi lembar observasi pra tindakan untuk mengetahui kondisi awal siswa yang akan dikenakan tindakan dan observasi untuk mengetahui keaktifan siswa.

4) Menyusun media pembelajaran

Guru menyiapkan semua media baik berupa potongan-potongan gambar, power point yang berkaitan dengan materi la disponibilité dan la volonté.

b. Melaksanakan tindakan

1) Guru memberikan apresepsi kepada siswa terkait dengan materi yang akan dipelajari pada hari itu. 
2) Siswa mengerjakan pretes dengan menggunakan kahoot yang berkaitan dengan konjugasi pouvoir dan vouloir. Setelah itu, guru memberikan lembar kerja berupa potongan-potongan gambar dan siswa menuliskan deskripsi tentang gambar tersebut.

3) Siswa membaca teks yang berkaitan dengan tache domestique yang di dalamnya terdapat kata kerja pouvoir dan vouloir, siswa menjawab pertanyaan yang disiapkan oleh guru.

4) Siswa terbentuk dalam kelompok-kelompok kecil untuk mendiskusikan isi teks yang telah dibaca secara individu.

5) Siswa menyampaikan informasi terkait isi teks tersebut.

6) Siswa kembali ke tempat duduk masingmasing untuk menuliskan teks sesuai dengan gambar yang diberikan oleh guru.

7) Siswa mempresentasikan hasil tulisannya di depan kelas.

\section{c. Observasi}

Kegiatan observasi dilakukan dengan cara mengisi lembar observasi oleh observer. Observasi meliputi kegiatan yang dilaksanakan guru dan siswa selama pelaksanaan tindakan.

\section{d. Refleksi}

Setelah pelaksanaan tindakan, dilakukan refleksi terkait dengan hal-hal yang dilaksanakan selama perencanaan dan pelaksanaan tindakan. Dalam refleksi ini akan didapatkan masukan dari siswa dan observer. Masukan-masukan ini yang akan dijadikan bahan perbaikan pada siklus kedua.

\section{Siklus 2}

a. Rencana tindakan

1) Membuat RPP

Kegiatan penelitian diawali dengan menyusun Rencana Pelaksanaan Pembelajaran untuk kelas XI IPS1 SMA Negeri 10 Yogyakarta dengan Kompetensi Dasar 3.2 yaitu mengekspresikan tindak tutur untuk menyatakan dan menanyakan kemampuan dan kemauan (la disponibilité et la volonté) melakukan suatu tindakan dengan memperhatikan fungsi sosial, struktur teks, dan unsur kebahasaan pada teks interpersonal dan teks transaksional tulis dan lisan, dan kompetensi dasar 4.2 menerapkan tindak tutur untuk menyatakan dan menanyakan kemampuan dan kemauan (la disponibilité et la volonté) melakukan suatu tindakan dengan memperhatikan fungsi sosial, struktur teks, dan unsur kebahasaan pada teks interpersonal dan teks transaksional tulis dan lisan, Adapun langkah-langkah pembelajaran yang akan dilaksanakan adalah:

a) Siswa membaca teks terkait dengan la tàche domestique.

b) Siswa mencatat informasi-informasi penting yang berkaitan dengan aktivitas domestique sesuai dengan pertanyaan yang diajukan guru.

c) Siswa berkelompok (setiap kelompok terdiri atas 4 siswa) dan secara aktif mendiskusikan aktivitas-aktivitas yang terdapat di dalam teks.

d) Siswa menemukan kesimpulan di dalam diskusi ini dan mempresentasikan hasil diskusinya di depan kelas.

e) Siswa kembali ke tempat duduk masingmasing dan secara mandiri menuliskan kegiatan yang berkaitan dengan tugas tugas domestique mereka.

f) Siswa mempresentasikan hasil tulisan mereka di depan kelas.

2) Menyusun lembar kerja

Lembar kerja yang harus disiapkan adalah lembar kerja berupa pretes, teks yang harus dibaca siswa pada bagian awal pertemuan, lembar diskusi siswa dan soal postes.

3) Menyusun instrumen penelitian

Instrumen penelitian yang disiapkan adalah lembar observasi kegiatan guru untuk memantau persiapan yang dilakukan guru sebelum melaksanakan tindakan, lembar observasi guru selama melaksanakan tindakan dan lembar observasi evaluasi pelaksanaan tindakan. Lembar observasi untuk siswa meliputi lembar observasi pra tindakan untuk mengetahui kondisi awal siswa yang akan dikenakan tindakan dan observasi untuk mengetahui keaktifan siswa.

4) Menyusun media pembelajaran

Guru menyiapkan semua media baik berupa potongan-potongan gambar, power point yang berkaitan dengan materi la disponibilité dan la volonté.

b. Melaksanakan tindakan

1) Guru memberikan apresepsi kepada siswa terkait dengan materi yang akan dipelajari pada hari itu.

2) Siswa mengerjakan pretes dengan menggunakan kahoot yang berkaitan 
dengan konjugasi pouvoir dan vouloir. Setelah itu, guru memberikan lembar kerja berupa potongan-potongan gambar dan siswa menuliskan deskripsi tentang gambar tersebut.

3) Siswa membaca teks yang berkaitan dengan tâche domestique yang di dalamnya terdapat kata kerja pouvoir dan vouloir, siswa menjawab pertanyaan yang disiapkan oleh guru.

4) Siswa terbentuk dalam kelompok-kelompok kecil untuk mendiskusikan isi teks yang telah dibaca secara individu.

5) Siswa menyampaikan informasi terkait isi teks tersebut.

6) Siswa kembali ke tempat duduk masingmasing untuk menuliskan teks sesuai dengan gambar yang diberikan oleh guru.

7) Siswa mempresentasikan hasil tulisannya di depan kelas.

c. Observasi

Kegiatan observasi dilakukan dengan cara mengisi lembar observasi oleh observer. Observasi meliputi kegiatan yang dilaksanakan guru dan siswa selama pelaksanaan tindakan.

d. Refleksi

Setelah pelaksanaan tindakan, dilakukan refleksi terkait dengan hal-hal yang dilaksanakan selama perencanaan dan pelaksanaan tindakan. Dalam refleksi ini akan didapatkan masukan dari siswa dan observer. Masukan-masukan ini yang akan dijadikan bahan menyusun kesimpulan penelitian.

\section{Data dan Teknik Pengumpulannya}

Data yang diperoleh dari hasil penelitian ini adalah data kualitatif dan data kuantitatif. Data kualitatif diperoleh dari hasil observasi aktivitas guru, hasil observasi aktivitas siswa, hasil respon siswa terhadap pelaksanaan tindakan dalam penelitian dan catatan-catatan observer. Data kuantitaif diperoleh dari hasil penghitungan angka-angka.

1. Sumber Data

Sumber data diperoleh dari siswa kelas XI IPS1 SMA Negeri 10 Yogyakarta tahun pelajaran 2019-2020 sejumlah 21 siswa terdiri atas 14 siswa perempuan dan 7 siswa laki-laki.

2. Teknik Pengumpulan Data

Teknik pengumpulan data pada penelitian ini adalah:

a. Observasi

Teknik observasi merupakan teknik pengumpulan data dengan mengadadakan penelitian terhadap objek penelitian.
Pelaksanaan observasi mengacu pada instrumen yang telah ditetapkan. Observasi yang dilakukan berkaitan aktivitas guru dan siswa. Hal-hal yang menjadi fokus pengamatan pada guru adalah berkaitan dengan perencanaan pembelajaran yang telah disiapkan guru dan pelaksanaan pembelajaran juga teknik evaluasi yang dilaksanakan. Sedangkan observasi yang berkaitan dengan aktivitas siswa meliputi aktivitas verbal dan nonverbal, sehingga dapat diketahui seberapa besar atensi siswa terhadap pelaksanaan pembelajaran dan seberapa besar peran siswa dalam kegiatan pembelajaran tersebut.

b. Tes

Teknis tes yang dilakukan untuk mengetahui keterampilan menulis siswa berkaitan dengan kompetensi la disponibilité dan la volonté adalah dengan mengerjakan tes esai berdasarkan gambar yang berkaitan dengan tâche domestique. Untuk menilai siswa digunakan pedoman penilaian berdasarkan DELF niveau A1 oleh Breton (2005: 86) yang telah disesuaikan.

\section{Teknik Analisis Data}

Analisis data dilakukan dalam penelitian untuk menarik kesimpulan dari seluruh data yang telah diperoleh. Data- data yng dianalisis adalah hasil observasi aktivitas guru dan siswa, hasil respon siswa terhadap pelaksanaan pembelajaran dan hasil evaluasi siswa. Data hasil evaluasi siswa dan hasil observasi aktivitas siswa dianalisis dengan angka-angka. Kriteria ketuntasan belajar siswa secara individu adalah 75, sementara kriteria ketuntasan belajar secara klasikal yaitu apabila terdapat $85 \%$ siswa telah mencapai ketuntasan belajar secara individu. Untuk menganalisis ketuntasan belajar secara klasikal dan aktivitas siswa digunakan rumus sebagai berikut:

a. Analisis Ketuntasan Belajar Klasikal digunakan rumus:

$$
\mathrm{NP}=\frac{R}{S N} \times 100
$$

$\mathrm{NP}=$ Nilai persentase

$\mathrm{R}=$ jumlah siswa yang memperoleh nilai $\geq 75$

$\mathrm{SN}=$ jumlah siswa seluruhnya

b. Analisis aktivitas siswa digunakan rumus:

$$
\mathrm{Pa}=\frac{A}{N} \mathrm{x} 100
$$

$\mathrm{Pa}=$ persentase aktivitas siswa

$\mathrm{A}=$ jumlah nilai tercapai

$\mathrm{N}=$ jumlah nilai penuh 
Tabel 1. Kriteria Aktivitas Siswa

\begin{tabular}{ll}
\hline Persentase Aktivitas Siswa & Kriteria \\
\hline $86 \% \leq \mathrm{Pa} \leq 100 \%$ & Sangat aktif \\
$68 \% \leq \mathrm{Pa} \leq 85 \%$ & Aktif \\
$51 \% \leq \mathrm{Pa} \leq 67 \%$ & Kurang aktif \\
$\mathrm{Pa} \leq 50 \%$ & Sangat kurang aktif \\
\hline
\end{tabular}

\section{Instrumen Penelitian}

Instrumen penelitian yang digunakan ada dua jenis, yaitu:

a. Instrumen pengumpul data, meliputi lembar observasi dan lembar tes siswa.

b. Instrumen pemandu analisis, meliputi tabel penskoran tes kemampuan menulis berdasar DELF A1, lembar ketuntasan dan kriteria keaktifan siswa.

\section{Indikator Keberhasilan}

Dalam kegiatan Penelitian Tindakan Kelas ini, kriteria keberhasilan ditetapkan jika $85 \%$ siswa memperoleh nilai di atas kriteria ketuntasan minimal atau di atas 75 .

\section{HASIL DAN PEMBAHASAN}

Penelitian Tindakan Kelas ini terdiri dua siklus dan diawali dengan pretes. Pada kegiatan pretes, siswa mengasosiasi gambar denga kata kerja yang sesuai. Gambar terdiri atas 16 aktivitas domestic dan 16 kata kerja acak. Setelah siswa selesai mengasosiasi gambar dengan kata kerja, siswa dibagi dalam 7 kelompok, setiap kelompok terdiri dari 3 siswa. Guru menampilkan aplikasi Kahoot yang berisi gambar dan kata kerja, siswa berdiskusi dalam kelompok kecil untuk dapat menyelesaikan soalsoal dalam Kahoot tersebut. Setelah seluruh siswa mengetahui jodoh gambar dengan kata kerja, lalu siswa diminta mengembangkan kalimat dengan menambahkan kata kerja pouvoir dengan subjek Je. Kata kerja tersebut adalah jeter la poubelle, laver la voiture, laver les vitres, étendre le linge, faire le lit, épousseter, cuisine, faire les courses, ranger, bilayer, nettoyer, faire le ménage, passer l'aspirateur, repasser, faire le linge dan faire la vaiselle. Nilai rata-rata siswa pada kegiatan prasiklus adalah 63,14., ada 11 atau 52,39\% siswa yang telah mencapai nilai antara $75-84$ dan masih ada 10 atau $47,61 \%$ siswa masih memperoleh nilai dibawah KKM.

\section{Deskripsi pelaksanaan siklus I}

Pelaksanaan siklus satu diawali dengan kegiatan Think yakni siswa secara mandiri mengerjakan lembar tugas terkait tugas domestik, dari 16 kata kerja tersebut, siswa membagi tugas untuk seluruh anggota keluarga. Kegiatan selanjutnya adalah Talk, pada kegiatan ini, siswa dibagi dalam kelompok kecil terdiri 3 siswa, mereka berdiskusi tentang cara mengkonjugasikan kata kerja pouvoir untuk seluruh anggota keluarga secara tepat. Write, pada kegiatan write ini, siswa mendeskripsikan tugas yang dikerjakan seluruh anggota keluarga untuk mewujudkan rumah yang bersih. Dengan konjugasi dan konjungsi yang tepat.

Rata-rata nilai pada siklus satu adalah 79,48 dan 6 atau 29\% siswa memperoleh nilai dibawah KKM sedangkan 15 atau 71\%siswa telah memperoleh nilai di atas KKM. Ada kenaikan 25,88\% dari nilai prasiklus.

Berdasarkan pengamatan verbal selama siklus satu, didapati $19 \%$ siswa belum aktif mengikuti diskusi, berbicara sendiri dan 19\% bercanda dengan temannya, sedangkan $48 \%$ siswa sudah dapat berinteraksi dengan baik dengan teman dan guru.

Berdasarkan pengamatan nonverbal menunjukkan bahwa $76 \%$ siswa antusias mengikuti pembelajaran dan $19 \%$ siswa masih sibuk dengan dirinya sendiri.

Berdasar hasil observasi aktivitas guru, menunjukkan guru telah menyiapkan rencana pembelajaran dengan baik, memberi kesempatan siswa untuk bertanya, berkepribadian baik, namun belum semua siswa memanfaatkan kesempatan bertanya yang diberikan oleh guru.

Berdasar respon siswa terhadap pelaksanaan pembelajaran menunjukkan bahwa 57\% siswa menyatakan bahasa Perancis termasuk bahasa yang sulit, $57 \%$ siswa mengetahui bahasa Perancis termasuk bahasa Internasional dan menjadi bahasa yang digunakan berkomunikasi di PBB, 86\% siswa termotivasi mempelajari bahasa Perancis dan $81 \%$ siswa memahami bahwa untuk dapat menulis diperlukan beberapa syarat, yakni memiliki kosa kata yang cukup, tata bahasa yang baik dan mampu mengaitkan antar bagian dengan baik sehingga membentuk kesatuan ide.

Hasil refleksi pada siklus satu menunjukkan bahwa penggunaan strategi Think, Talk, Write masih ada kelemahan yakni pada saat diskusi, belum semua siswa memperhatikan penjelasan teman, siswa masih merasa malu untuk menyampaikan gagasan sehingga diskusi kurang optimal. 
Perbaikan yang akan dilakukan pada siklus kedua adalah:

1. Anggota kelompok diskusi diubah, komposisi siswa aktif dan kurang aktif diseimbangkan.

2. Tetap digunakan aplikasi Kahoot untuk menyemangati tim dalam diskusi.

3. Guru memberikan perhatian lebih kepada siswa yang masih terlihat malu dan belum fokus pada kegiatan pembelajaran.tes pada siklus dua tidak lagi menggunakan gambar, namun secara mandiri siswa menyebutkan kata-kerja yang akan digunakan dalam tulisan mereka.

\section{Deskripsi pelaksanaan siklus II}

Pada kegiatan Think siswa secara mandiri mengisi lembar kerja yang disiapkan guru dengan mengisi 3 kolom tersedia, kolom pertama diisi dengan kata kerja yang telah dikuasai siswa pada pertemuan sebelumnya, kolom kedua diisi dengan pembagian tugas bagi seluruh anggota keluarga, sedang kolom ketiga diisi dengan waktu pelaksanaan kegiatan tersebut.Kegiatan Talk, siswa diskusi dalam kelompok kecil, dalam diskusi tersebut siswa menjawab pertanyaan guru dengan kata tanya qui (siapakah), que (apakah), quand (kapankah), où (dimanakah), pourquoi (mengapakah), comment (bagaimana). Kegiatan write, siswa menulis narasi sesuai isi kolom-kolom yang telah disiapkan. Secara konsisten, siswa merangkai narasi berdasar subjek, kata kerja, keterangan-ketrangan lain yang mendukung, sehingga menjadi kalimat yang runtut tentang tugas domestik.

Perolehan nilai rata-rata pada siklus kedua adalah 81,62 dan terjadi peningkatan sebesar $2,69 \%$ dibandingkan hasil nilai rata-rata pada siklus pertama. Jumlah siswa memperoleh nilai di bawah KKM ada 3 siswa dan 18 siswa sudah mencapai nilai di atas KKM.

Pengamatan secara verbal didapati $48 \%$ siswa atau 10 siswa telah mengikuti diskusi dengan baik, memberikan masukan sesuai materi yang dibahas. Pengamatan non verbal menunjukkan bahwa $76 \%$ siswa atau sekitar 16 siswasudah antusias mengikuti pembelajaran dan $81 \%$ siswa sudah memperhatikan penjelasan guru dan tidak lagi malu dalam menyampaikan gagasan.

Berdasarkan respon siswa diperoleh 12 siswa atau $57 \%$ siswa menyadari bahwa bahasa Perancis adalah baha internasional dan digunakan untuk komunikasi di PBB, $86 \%$ siswa memiliki motivasi kuat untuk belajar bahasa Perancis, dan dengan strategi Think, Talk, Write siswa dapat menikmati pembelajaran secara bertahap, melalui berpikir mandiri, diskusi dan menuliskan gagasan dengan runtut.

Hasil refleksi siklus kedua terdapat peningkatan hasil belajar sebesar $15 \%$ dibandingkan hasil belajar pada siklus pertama, namun masih ada $14 \%$ siswa yang belum mencapai ketuntasan belajar, karena masih kurang memiliki daya juang untuk mengikuti seluruh proses pembelajaran, perlu pemberian motivasi khusu bagi siswa-siswa tersebut.

\section{Pembahasan antar siklus}

Hasil belajar pada prasiklus belum ada satu siswapun yang berhasil masuk kategori amat baik yakni 91-100 dan juga belum ada siswa yang masuk kategori baik, yakni rentang nilai 83-90. Ada 11 siswa masuk kategori cukup, 1 siswa masuk kategori kurang dan 9 siswa masuk kategori kurang sekali. Nilai ratarata yang diperoleh siswa pada prasiklus sebesar 63,14.

Sedangkan pada siklus pertama, menunjukkan adanya kenaikan kategori. Ada 5 siswa masuk kategori amat baik, dengan rentang nilai 91-100, ada 4 siswa masuk kategori baik dengan rentang nilai 83-90, terdapat 6 siswa msuk kategori cukup dengan rentang nilai $75-82$, dan ada 5 siswa masuk kategori kurang dengan rentang nilai 66-74, sedangkan siswa masuk ke dalam kategori kurang sekali terdapat 1 siswa dengan rentang nilai kurang 66. Nilai rata-rata siswa pada siklus pertama sebesar 79,48, sehingga ada kenaikan rata-rata nilai siswa dari prasiklus sampai siklus satu sebesar 25,88\%, sedangkan nilai rata-rata siswa pada siklus kedua sebesar 81,62, sehingga ada kenaikan sebesar 2,69\% dari nilai rata-rata di siklus satu point dari ratarata nilai siklus satu ke siklus kedua.

Hasil belajar yang diperoleh pada siklus kedua, dapat dijelaskan sebagai berikut, siswa masuk kategori amat baik sejumlah 9 siswa, masuk kategori baik sejumlah 4 siswa, masuk kategori cukup sejumlah 5 siswa, tidak ada siswa yang masuk kategori kurang, namun ada 3 siswa masuk dalam kategori kurang sekali.

Tabel 2. Ketuntasan Hasil Belajar Siswa

\begin{tabular}{ccc}
\hline \multirow{2}{*}{ Uraian } & \multicolumn{2}{c}{ Hasil Belajar Bahasa Prancis } \\
\cline { 2 - 3 } & $\begin{array}{c}\text { Siswa } \\
\text { Tuntas }\end{array}$ & $\begin{array}{c}\text { Siswa Tidak } \\
\text { Tuntas }\end{array}$ \\
\hline Data Awal & $11(52,39 \%)$ & $10(47,61 \%)$ \\
Siklus I & $15(71,42 \%)$ & $6(28,58 \%)$ \\
Siklus II & $18(85,71 \%)$ & $3(14,29 \%)$ \\
\hline
\end{tabular}


Berdasarkan tabel 2 di atas dapat dijelaskan bahwa ketuntasan belajar siswa adalah sebagai berikut: hasil belajar pada prasiklus menunjukkan ada 11 siswa telah tuntas belajar atau $52,39 \%$ siswa telah tuntas belajar, sedangkan 10 siswa belum tuntas belajar atau $47,61 \%$ siswa belum tuntas belajar.
Pada siklus pertama didapat hasil 15 siswa tuntas belajar atau 71,42\% dan terdapat 6 siswa belum tuntas belajar atau $28,58 \%$, sedangkan pada siklus kedua diperoleh hasil 18 siswa tuntas belajar atau $85,71 \%$ dan 3 siswa belum tuntas belajar atau $14,29 \%$.

Hasil Belajar Bahasa Prancis berdasar Data Awal, Siklus I, dan Siklus II

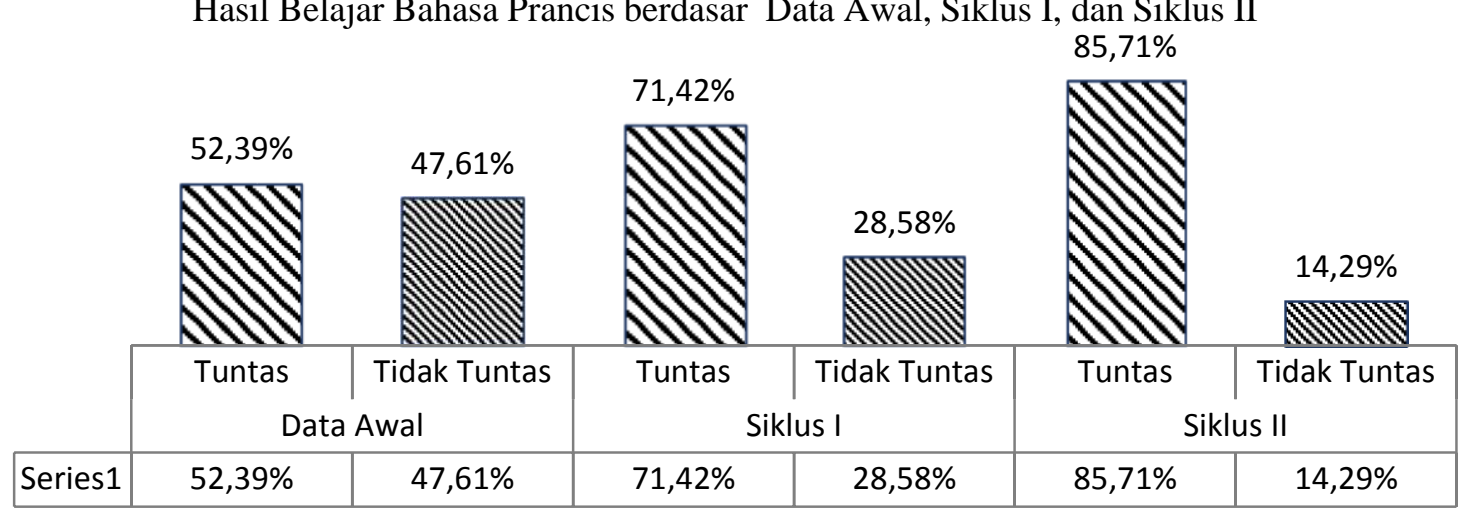

Gambar 1. Diagram Hasil belajar Bahasa Perancis berdasar data awal, silkus satu dan siklus 2

Dari grafik di atas dapat dijelaskan adanya peningkatan hasil belajar pada setiap siklus pembelajaran. Berdasarkan hasil pembelajaran pada pra siklus dibandingkan dengan hasil pembelajaran pada siklus pertama, terdapat peningkatan 19,03\%, sedangkan berdasarkan hasil belajar siklus pertama dan siklus kedua terdapat peningkatan $14,29 \%$. Peningkatan hasil belajar dari pra siklus sampai dengan siklus kedua menunjukkan ada peningkatan hasil sebesar 33,32\%.

\section{SIMPULAN}

Dengan

menerapkan strategi pembelajaran Think, Talk, Write dapat meningkatkan keterampilan menulis siswa dalam bahasa Perancis. Berdasarkan analisis data hasil penelitian didapati persentase ketuntasan belajar pada prasiklus sebesar 52,39 $\%$ dan persentase ketuntasan belajar pada siklus satu sebesar $71,42 \%$, sehingga antara prasiklus dengan siklus satu ada kenaikan ketuntasan belajar sebesar 19,03\%. Sedangkan ketuntasan belajar pada siklus kedua sebesar 85,71\%, sehingga antara siklus satu ke siklus kedua ada peningkatan persentase ketuntasan belajar sebesar 14,29\%. Ketuntasan belajar dari prasiklus sampai dengan siklus kedua sebesar $33,32 \%$. Sedangkan ketercapaian nilai rata-rata pada prasiklus sebesar 63,14 dan pada siklus satu nilai rata-rata hasil belajar siswa adalah 79,48 , sehingga ada kenaikan nilai rata-rata yang dicapai antara prasiklus dengan siklus satu sebesar $25,88 \%$, dan nilai rata-rata hasil belajar pada siklus kedua adalah 81,62 sehingga ada peningkatan sebesar 2,68\% dari siklus satu. Kenaikan nilai rata-rata hasil belajar dari prasiklus ke siklus kedua sebesar $29,27 \%$. Dengan demikian penggunaan strategi Think, Talk, Write dapat meningkatkan keterampilan menulis pada kompetensi la disponibilité dan la volonté bagi siswa kelas XI IPS1 SMA Negeri 10 Yogyakarta tahun pelajaran 2019-2020.

\section{DAFTAR PUSTAKA}

Arifin, Winarsih dan Farida Sumargono.1991. Dictionnaire Français Indonésien. Jakarta: Gramedia Pustaka Utama.

Arikunto, S. (2009). Prosedur Penelitian; Suatu Pendekatan Praktik. Jakarta: Rineka Cipta.

Himber, Céline.2006. Le Mag Méthode de Français. Paris: Hachette.

Himber, Céline.2006. Le Mag Cahier d'Exercise. Paris: Hachette.

Huda, Miftahul. 2016. Model-Model Pengajaran dan Pembelajaran. Yogyakarta: Pustaka Pelajar.

Jamet, Marie-Christine.2006. Préparation à l'examen $d u$ DELF. France: FLE Hachette.

Pringgawidagda, Suwarna.2002. Strategi Penguasaan Berbahasa. Bandung: Addicipta.

Tagliante Christine.1991. L'evaluation.Paris: CLE Internationale. 